\title{
Multiple temporalities in violent conflicts: Northern Ireland, the Basque Country and Macedonia. ${ }^{1}$
}

\author{
Joseph Ruane and Jennifer Todd \\ j.ruane@ucc.ie, jennifer.todd@ucd.ie
}

\section{Introduction}

Ethnic conflicts are multi-layered and multi-temporal in their causality. ${ }^{22}$ To understand the meaning, function and consequences of violence in these conflicts requires us to place it in historical, as well as spatial and relational, context. In this paper, we compare three conflicts - Northern Ireland, the Basque Country and Macedonia. ${ }^{3}$ We show in each case how longer-term structures and processes defined the shape of conflict, constrained the options of the parties to it, informed the meanings of violence, and shaped the conditions under which agreed settlement became possible and the dangers that remain even after agreement is reached.

After an initial clarification of concepts and claims, we examine each case, showing the multi-temporal constitution of violent conflict, its course and ending, and the significance of the agreed settlement. This provides the basis for an analytic comparison of the role of violence in each case.

\footnotetext{
${ }^{1}$ Acknowledgements to the Irish Research Council for the Humanities and Social Sciences and the Irish Department of Foreign Affairs for funding the Patterns of Conflict Resolution project, 2010-11, and to co-participants, in particular to Lidija Georgieva, Ardit Memeti, Ali Musliu and Pascal Pragnere, and more recently to Roland Gjoni. This is a long version of a paper to be published in a volume edited by L. Bosi. A shorter version will be presented at the conference.

${ }^{2}$ We use the term 'ethnic conflict' in a broad sense to mean any intra-state conflict with a social basis in a culturally-differentiated population

${ }^{3}$ The Republic of Macedonia is a recently formed independent state with a population of about 2 million. The autonomous community of the Basque County is a self-governing region within Spain, with a population of 2.2 million. Northern Ireland is a devolved region of the United Kingdom with a population of 1.8 million.
} 


\section{Securitity}

\section{Multiple temporalities in conflict processes \\ Conflict and settlement}

Violence within ethnic conflicts typically emerges in response to contingent short-term opportunities and threats, although it may then take on a logic of its own (Laitin, 2007; Kalyvas, 2006). Much of the effort in conflict resolution goes into stopping cycles of violence and counter-violence (Zartmann, 1989; Hartzell and Hoddie, 2007; Mattes and Savun, 2010).

These cycles, however, arise out of longer-term processes. For example, processes of nation-state-consolidation, with the build-up of state coercive capacity and practices of territorial governance that are implicitly or explicitly biased against one or another group, give incentives to violence, taken when the opportunity arises (Wimmer, 2002; 2013; Malesevic, 2013). These processes in turn are shaped by slowly changing patterns of demography and economy, spatial relations, and identity (Flora, 1999).

An adequate explanation of the course of any particular conflict, including its violent episodes, requires contextualisation at each of the levels, which constitute it (Bosi et al, 2015, this volume). It also requires identification of the interrelations between the levels. Most generally, longer-term structures set limits on shorter-term processes, embedding horizontal inequalities between populations, defining constraints on reform and compromise, and thus providing more or less strong incentives to conflict and violence. For example, whether or not a march turns violent, a social movement becomes radicalized or a single episode of violence escalates to a society-wide one is largely determined by middle range social institutions and longer term social structures. ${ }^{1}$ Contextualizing action and choice in embedded structural contexts of different temporal depth reveal how different layers of the past shape the present and do so not just through 'mythical' perceptions and ideologies but also through real social processes and structural relations, which limit available choices and define likely outcomes.

While slow moving, these long-term structures are themselves in process of

\footnotetext{
${ }^{1}$ For example, both Wright (1987) and Della Porta (2013) show comparatively that state structures and embedded practices affect whether or not protest movements become violent. Brass (1998), shows the role of embedded habits of policing and politics and Varshney (2002), the role of crosscommunity institutions in rioting and the spread of violence. Stewart (2014) shows the impact of horizontal inequalities on the likelihood of violent conflict.
} 
change, with their own moments of transition - what Katznelson (2003) calls critical junctures - when more radical possibilities for change and settlement open up.

At this point, intervention can have a radical impact, sometimes determining the form of an emerging path. In the case studies that follow we show the varying effects of actions and interventions (be they violent episodes or settlement initiatives) on the slower moving patterns that converged to make conflict likely.

Violence is typically conceived in terms of insurgent or military action, but it is also a characteristic of coercive institutions and the cultural and structural relations they uphold. As action, violence has lasting social consequences when it embeds itself at these deeper levels, for example by creating spatial, social or cultural inequalities that are then stabilised by coercive power. In specific circumstances, violent action may help undo such structures of coercion, thus opening up the possibility of constructing relationships of a less contentious kind. Through the case studies, we ask how far and when violence shifted a society from the path it was already on, and whether it affected upon long-term as well as short-term processes.

This approach has implications for the ending of violence and the achievement of political agreements. Common explanations of the end of violence focus on short-term factors - military defeat of terrorism (Bew et al, 2009) or military stalemate (Zartmann, 1989). Political settlement is typically explained in terms of short-term strategies such as confidence building, or particular institutional innovations, such as power sharing (Hartzell and Hoddie, 2007). Yet if longer-term relations, inequalities and structural processes underlie conflict, intervention in them is necessary if a stable settlement is to be achieved. There is evidence that in protracted conflicts the actors themselves, including the militants, judge the significance of short-term setbacks or opportunities in light of longer-term trends (see for example, Tonge et al, 2011). In the case studies that follow, we show that intervention in long-term processes helps settlement to be achieved.

\section{European temporalities}

We have chosen to compare three conflicts - in Northern Ireland, the Basque Country and Macedonia -, which differ in their geo-political and geo-historical context, in the historical depth and extent of violence, in the social processes, and political constraints to which the societies and states have been subject, and in the form of settlement reached. They are sufficiently similar in their wider European context to permit meaningful comparison. Our aim is to throw the multi-temporal processes 
involved in each conflict into sharper relief by comparison with the others, while developing general insights into the role of longer-term processes in generating violent conflict.

The cases we are concerned with emerged from long-term processes of state, empire and nation building and later contraction and/or dissolution. In schematizing this, we draw on Stein Rokkan's theoretical approach to Europe's historical development (Flora, 1999, 95-273) adapting and elaborating this to distinguish three phases of postmedieval development particularly relevant to our case studies. ${ }^{1}$

(i) the early-modern period: this period was one of state and empire formation, emergent agricultural and merchant capitalism, religious reformation and confessional division, the opening up of global trade routes, and emergence of a system of sovereign states throughout Europe and interlocking with the Ottoman empire. Each of our cases was located at a distinctive point within three different state-empires (British, Spanish and Ottoman).

(ii) The modern period: this period saw the birth of the bureaucratic, liberal democratic, nation state; industrialization and urbanization on a large scale; major advances in transportation and mass communication; the spread of literacy; the birth of nationalism and the emergence of bounded national societies; and differential processes of imperial expansion and contraction. Each of our cases was defined by the timing and manner of transformation of the state, to which it was subject, and the expansion and contraction in the larger state-empires to which it belonged.

(iii) the contemporary period: one of the intensifying globalization of trade, financial flows and popular culture; replacement of a two-bloc world by a multipolar one; weakening of the boundaries, autonomy and status of national societies.

We also take from Rokkan his view of modern societies as layered phenomena. Successive epochs do not create social structures and divisions anew, but draw on and incorporate the structures and institutions of the period that preceded them. Whether and to what extent these elements are changed in their functioning in the new epoch, or instead shape its development, is a matter for empirical analysis in each case.

\footnotetext{
${ }^{1}$ For the need for both adaptation (to include states beyond Western Europe and highlight the imperial contribution) and elaboration (to the current phase of globalisation), see Ruane 2003.
} 


\section{Securiaty}

\section{The three cases}

\section{Northern Ireland}

A sustained period of violence began in Northern Ireland in 1969 and lasted until the late 1990 s, resulting in over 3,500 deaths. ${ }^{1}$ Explanations for the conflict tend to be framed in terms of short term processes: communal mobilisation and countermobilisation around civil rights in the late 1960s leading to a cycle of state repression and paramilitary violence which came to a close only when the evidence of stalemate (on some interpretations defeat) became overwhelming in the mid-1990s. This leaves much unexplained: why reform was not offered earlier; why the Northern Ireland regime collapsed so quickly; why the British state was unable for so long either to end violence or to broker a viable settlement amongst the Northern Ireland political parties. To answer these questions requires attention to multiple layers of structure and temporality. ${ }^{2}$

\section{Multi-temporality in the constitution and reconstitution of the Northern Ireland conflict}

English state building began in the medieval period and the late medieval English state was one of the most centralized in Europe. A new phase of state building began in the $1520 \mathrm{~s}$ and this time was extended to Wales, Scotland and Ireland (Pocock, 2005, 24-103). Wales was annexed during the 1530s. Scotland entered a union of Crowns in 1603 and of parliaments in 1707. Ireland, though a lordship of the English Crown from the end of the $12^{\text {th }}$ century, proved much more difficult to integrate, and was secured only by the dispossession of the vast majority of the island's native, Catholic, landowners and their replacement with Protestant settlers from England and Scotland. In Ulster, in particular the process of displacement and replacement took place at all levels (Canny, 2001). Thereafter political stability depended on the continued economic containment and political exclusion of the Catholic majority population, achieved by the concentration of power in British and Protestant hands. ${ }^{38}$ This system of rule was inherently conflictual

\footnotetext{
${ }^{1}$ Both the dating of 'the conflict' and the death count are contentious, see McKittrick et al., 2004, 13-21.

${ }^{2}$ The analysis below is a development of Ruane and Todd, 1996, 2007, 2014. See also Wright, 1987.

3 There were cross-cutting divisions within the Protestant population, so that significant democratization in Protestant access to the means of violence coexisted with class and
} 
but from the end of the $17^{\text {th }}$ century Catholics had lost the capacity to challenge it, and for the British to reconstitute or reform it risked general destabilization.

Rebellion in 1798 was crushed, but potential French involvement highlighted the dangers to British security. The British government pushed through an Act of Union (1800) with the object of strengthening its control and allowing Catholic grievances to be addressed without provoking a Protestant response. However, Catholic emancipation was delayed until 1829 and achieved then only by very Catholic mobilisation. As the century progressed, an economic cleavage was added to the political and religious ones: the Protestant North-East prospered under the Union, developing a local version of British industrialism; the predominantly Catholic rest of the country experienced economic dislocation, a massive famine at mid-century, and de-industrialisation. What chance there had been to persuade Catholics to accept the legitimacy of the British state had been lost: by the end of the century, they had become nationalist and were demanding Home Rule as a matter of right. In contrast, Ulster unionists, overwhelmingly Protestant, opposed it and mobilised militarily against any attempt to impose it on Ulster.

Home Rule was legislated for in August 1914 but its implementation was suspended for the duration of the war. Ulster unionists won (temporary) 6-county exclusion. Two years later, taking advantage of the war, radical nationalists staged a rising. It was rapidly put down, but it began a process of wider politicization and radicalization. Using a combination of political agitation and, after 1919, a campaign of violence, radical nationalists made British rule unworkable. They succeeded in getting a higher degree of independence sooner than would have been achieved by parliamentary means alone. However, the price was partition: with the location of the border determined by balance of forces on the island. Unionists secured their own (devolved) parliament within the United Kingdom.

The formation of Northern Ireland (1920-1) reconstituted the historic system of Catholic disadvantage with Protestant power and privilege backed by the British state. During the decades that followed Northern Ireland achieved stability through a coercive, discriminatory and clientelist mode of government. It reproduced sectarian division at the same time as Catholic weakness, undermining any possibility of the state achieving legitimacy among Catholics. With the development of a nationally cohesive and socially egalitarian Britain in the post-war period, new opportunities opened. Radicals,

denominational differentiation in control of property and politics. 
nationalists of different hues, and liberals in the Civil Rights Movement of the late 1960s put the constitutional issue to one side and campaigned for reform in Northern Ireland. The movement alarmed sections of unionists who responded by counter-mobilisation, repressive policing, and loyalist attacks on civil rights marchers and Catholic neighborhoods. The Irish Republican Army (IRA) reemerged, first as community defenders and later as insurgents against the state. The British state supported the unionist government militarily and politically, while backing (most of) the civil rights demands. When this failed to win stability, it instituted Direct Rule from London (March 1972) thus ending unionists' political rule but remaining reliant on them in the security forces, civil service and the higher reaches of the economy. Violence intensified in the years immediately after Direct Rule and continued for another quarter century.

So profound a political crisis and so rapid a descent into violence requires a multi-leveled explanation. Viewed at the local level and over the very long term, it was yet another episode in a local struggle over power, property and security that began with the period of the plantations. Viewed geo-politically, it was a manifestation of a long and uneven Catholic political and economic recovery, which began throughout the island in the $18^{\text {th }}$ century, continued after 1921 and in the 1960 s made possible a serious challenge to the political structures of unionist dominance.

Other processes of different time-depths also helped shape the context out of which conflict had emerged: the chronic long-term failure of British institutions in Ireland to secure general legitimacy which made violence an option for all sides; the decline of the $19^{\text {th }}$ century industrial economy of the Irish north-east and the growing economic dependence of Northern Ireland on the British state; the contradictions that Catholics encountered in dealing with a state that simultaneously showed a benign (educational, welfare), discriminatory (public sector employment) and repressive (security) face; the as yet incomplete British transition - at least in Ireland - from quasi-imperial habits of indirect rule and harsh response to revolt to a state based on equal rights for all (Ruane and Todd, 1996). These processes continued as the United Kingdom transformed itself from a post-imperial national society in the 1960 s to a highly diversified and multicultural polity in the 1990 s. 
The significance of settlement

With Direct Rule in 1972, the British government's aims were to restore stability, this time by creating a devolved settlement that would have the support of both unionist and nationalist communities. The 'Sunningdale' experiment, agreed in December 1973 involved power sharing between moderate nationalists and moderate unionists and an 'Irish dimension' to give formal recognition to the Irish identity of nationalists. In less than five months, a mass loyalist (Protestant) workers strike brought down the new power-sharing executive. It took a further quarter century for another cross-community agreement to be reached, the Good Friday Agreement (GFA) of 1998, this time paralleled by an end to violence and including the extremes as well as the moderates in a power sharing executive with an Irish dimension.

Why did it take so long? How has the GFA survived while Sunningdale so quickly failed? We have argued elsewhere that the difference lies in a change in the longer term conditions of conflict: in the repositioning of the British government in respect of the communities, and in a substantive equalization of the communities in every field (Ruane and Todd, 2007; 2014). This began with an Irish government role in policy-making (the Anglo-Irish Agreement of 1985) and progressed through a strong and effective Fair Employment Policy (1989), projected reforms of security and cultural institutions (after 1998), and new channels of cross-border institution-building. It was guaranteed by an internationally ratified British-Irish agreement to enact the will of a majority in respect to constitutional (British or Irish) preference, and to respect the rights of all to be and to be recognised as British or Irish or both. This was a new political configuration. It meant that for the first time the structural relations of Catholic inequality and Protestant power, established by plantation, reconstituted in an urban-industrial setting in the $19^{\text {th }}$ century, and actively maintained by the British state was being dismantled by the British government and that this was guaranteed internationally.

Violence played a role in provoking these changes. It was not, as some unionists claimed, that these were concessions to the IRA, nor were they 'fig-leafs' to cover the IRA's failure to achieve a united Ireland. Nor was it, as some republicans latterly claimed, that the struggle had been for 'equality' all the time. Rather, increasing public support for republicanism stimulated the Irish government to propose a new track of British-Irish policy (Todd 2013) and, in the complex processes by which the British and Irish governments planned, negotiated, and finally brokered an agreed settlement, the balance 
of coercive power was one element in the wider power balance that they took into account. The latter had changed such that nationalists could no longer be marginalised, nor - as an increasing $40 \%$ of the population and of the voters - treated as a 'minority' whose identity and aspirations were of lesser importance than those of the 'majority'. But it remained unthinkable to force or even to try to persuade unionists to Irish unity: the destabilising potential of armed and determined loyalists remained too strong. The settlement was legitimated by a set of egalitarian and human rights principles, and a new and more open concept of sovereignty (Meehan, 2004). That these finally prevailed pushed hard by the two governments and the US in an effective negotiation process was in part because nothing else could cope with a situation of relatively equal power balance of the two blocs, with uncertainty whether and when the demographic and political balance would shift in the future.

The historic significance of the GFA was that for the first time the British government had disengaged from its dependence on and privileged support for the Protestant community and was creating a political system open to all sections of the population and open to further change. Is this an undoing of the longer-term conditions of conflict? With a loyalist flags protest (2012), loyalist mobilisation (2013) and near political breakdown (2014), it is clear that conflict remains (Nolan, 2014). While significant structural and institutional change has taken place, cultural change -both in the everyday embeddedness of cultural division and in the public place of British and Protestant symbolism - is slow and deeply contested. The battle is over the trajectory of the society. Is the implementation process now complete and British rule here to stay? Or are the principles of the CFA iterative, requiring ongoing changes in institutions and public culture long before constitutional change becomes possible? While this continues to divide unionists and nationalists, the historic conflict is far from undone (Ruane, 2014).

\section{The Basque Country}

The militant separatist group, ETA, began a campaign of violence against the Spanish state in 1968 with the goal of an independent and united Basque Country; the campaign ended only in 2011. This, however, is but one strand of a much broader Basque nationalist movement that has challenged the Spanish centre from the late $19^{\text {th }}$ century. A political settlement has been in place since the Basque Statute of Autonomy was accepted by a narrow majority in 1979. There is, however, widespread dissatisfaction that 
it has not led to further autonomy. To understand the dynamics of nationalism in the Basque country and its internal dynamic, we have to situate it within the multi-layered processes that shaped it.

\section{Multi-temporal processes and the constitution of conflict}

As in the case of Britain, Spanish state- and nation-building had uneven success. ${ }^{1}$ It began as the expansion southwards of the northern kingdoms into territories recovered from the Moors and was completed with the conquest of Granada in 1492. The final stage was achieved by the union of the crowns of Castile and Leon. This was in principle a union of equals, but Castile was the larger and stronger partner and became the political centre into which the regions would be integrated. Resistance came mainly from Catalonia with its orientation to the Mediterranean and historic ties to France. Two Catalan rebellions ended in defeat, and the second one in 1714 saw it stripped of its fueros (regional institutions and rights). In contrast, the Basques kept their fueros for another century and a half. Although also bordering France, their relationship was more fractious and they benefitted from their strategic importance in the chain of trade linking Castile with Northern Europe and the North Atlantic (Medrano, 1995, 21-28).

Basque autonomy would become an issue in the $19^{\text {th }}$ century as Spain adjusted to the loss of its empire and began its long and difficult transition to economic and political modernity. The strong and absolutist Spanish state of the $18^{\text {th }}$ century became a battleground between rival economic interests and conflicting political and religious ideologies, further complicated by political factionalism and dynastic rivalry. At issue was the degree to which the state should be centralised and the autonomy of the regions reduced, the position of the traditional elites and the question of popular political access, the burden of taxation, the wealth and power of the Church and the role of religion in Spanish society, the uneven progress of agricultural and industrial capitalism and contrasting views about how it might be speeded up, the conditions of national progress and the reasons for Spanish decline (Junto and Schubert, 2000; Medrano, 1995, 56-68). Much of the conflict was confined to the elites, but it had broader ramifications and open conflict could trigger popular revolt.

\footnotetext{
${ }^{1}$ For analytical overviews, see Linz 1973; Smith and Mar-Molinero, 1996, pp. 1-30; Medrano, 1995; Mees, 2003.
} 
The divisions twice converged in wars of dynastic succession (the Carlist Wars of 1833-39, and 1872-76), with rival claimants supported on the one hand by the traditionalist Carlists and on the other by centralising liberals. On each occasion the Basques sided with the Carlists for religious and economic reasons, and also, crucially, as a way of retaining their fueros. The final defeat of Carlism in 1876 saw their abolition, and nurtured a deep sense of Basque grievance. But other factors also contributed to the emergence of a separatist Basque nationalism. The new political and economic order opened up the Basque region to rapid industrialisation and exposed it to new class, urban-rural and cultural divisions and to an inflow of immigrants from other parts of Spain. Separatist nationalism was a reaction to this. It was conceived in a quasi-racist kind, ruralist, anti-centralist, anti-capitalist, form with a marked 'nostalgic' aspect and had limited appeal (Muro, 2005; Conversi, 1997; Mees, 2004). But there was substantial support for Basque autonomy.

The issues that had divided Spain in the $19^{\text {th }}$ century continued to do so in the $20^{\text {th }}$ century, given new forms and further depth by the crisis of 1898 , the extension of the franchise, and the advance of industrialisation, socialism and anti-clericalism. Basque nationalists continued to press for autonomy and, along with the Catalans, espoused federalism in the 1920s, briefly securing autonomous status in the Second Republic. By this stage the multiple lines of tension had converged into a single political opposition, for or against the Republic, and the Franco-led rebellion produced civil war, with Basques and Catalans siding with the Republic.

Franco's regime was not simply violently imposed; it was violently maintained for reasons that were partly punitive and vindictive, and partly a response to continued conspiracy, challenge and subversion. But there was also symbolic violence in the attempt to impose a single model of Spanishness - Catholic, Castilian, traditional and imperial - on the whole of Spain (Grugel and Rees, 1997). While superficially successful in that it further diluted the regional cultures and languages, it produced a reaction that undermined any possibility of eventual success.

That reaction was the context in which ETA began its campaign of violence. The national goals which ETA set for itself came directly from the more radical versions of $19^{\text {th }}$ century Basque nationalism, purged of its racist assumptions. It also modelled itself on Third World liberation movements. Its intention was to de-colonise the Basque region and violence was to be used to provoke the state to counter-violence that would in turn provoke a wider Basque mobilisation. The strategy had a degree of success in the early 
period, and ETA played a significant role in the Spanish transition to democracy, by killing Franco's designated successor, Carrero Blanco, and by foregrounding the urgency of the regional question. $0 \mathrm{n}$ the other hand, even a democratised Spanish centre was not willing to entertain its goal of Basque independence.

Spain's 1978 Constitution was intended as a compromise that would reconcile democrats, monarchists and military, regionalists and centrists, in a democratic, unitary state and it represented by far the most radical regionalisation of any European state at the time. The regions would enjoy a high measure of autonomy that over time could be expanded, while remaining within the framework of a unitary Spanish state (Wilson and Keating 2011, Comas, 2003). The Constitutional referendum of 1978 failed to secure a majority in the Basque Country but the 1979 Statute of Autonomy was supported by a narrow majority. Unlike the Constitution, it recognised the fueros, and included the right of the Basque Country to raise its own taxation before transmitting a segment to the central government. For ETA, however, this was a defeat and it continued its campaign.

The 1980s and 1990s were decades of economic and social transformation in the newly democratic Spain. The regional question was, however, far from settled and the centre resisted granting further autonomy to the strong regions (as in the 'coffee for all' decrees of the 1980s and 1990s (Comas, 2003, 49-50). In the Basque Country, the PNV usually the major party in the Autonomous Community (AC) government - enacted policies that ensured both greater economic development and greater social equality than in the rest of Spain (Goikoetxea, 2013). They were too weak in the central parliament to leverage concessions on further autonomy (Idoiaga, 2006; Comas, 2003) and even moderates remained unhappy with the autonomy achieved.

ETA violence was met by exceptional security responses by the Spanish state (Heiberg, 2007, 42-3; Conversi, 2010). There were also attempts to broker an end to violence, all of which failed, as much from governmental refusal to give concessions as from ETA intransigence (Idoiaga, 2006; Pragnere 2011; Keating and Bray, 2007; Keating and Wilson, 2011). Eventually increasing public anger with the campaign, overt opposition, falling sympathy and improved security measures, in the context of international mediation, convinced ETA to end the campaign (Heiberg, 2007; Pragnere, 2011). Although formally undefeated, and without concessions by the state, it declared a ceasefire in 2011 and an end to its campaign in 2012. 


\section{The significance of settlement}

The search for a political settlement to the Basque conflict began with the death of Franco and, by comparison with Northern Ireland, was quickly achieved. Agreement was reached on the Statute of Autonomy in 1979. It can be seen as a compromise between two existential imperatives, with the terms of the compromise set by the balance of power between them. The Spanish state would not entertain the possibility of secession by either the Basque country or Catalonia. If by the late twentieth century the British state could declare that it had 'no selfish strategic or economic interest' in holding onto Northern Ireland, ${ }^{1}$ the Spanish state had both in the 1970s and later. It had a clear economic interest in retaining its two most advanced and wealthy regions, and a strategic interest in stopping a process of state contraction that had begun with the end of empire and if it continued would relegate Spain to one of Europe's small and backward states.

Basque nationalism was divided between independentists and autonomists. Its maximal goal was a unified Basque-speaking homeland. This, however, was from a weak basis: it was a region divided by an international frontier in which - even on the Spanish side - not all citizens were Basque, not all Basques were nationalist, and not all nationalists wanted independence. In the early 1980s in the Basque AC, still almost half of the population felt more Spanish than Basque, the Basque language was spoken only by a fifth of the population, and only a quarter wanted full independence (Keating, 2001, pp 80-81; Conversi, 1997, 163). Autonomy was as much as could be achieved politically.

ETA continued its campaign. But while violence became self-sustaining, it achieved little: it weakened Basque nationalism by dividing it. Meanwhile autonomy was showing some results. Nearly half of Basques, and a full $75 \%$ of young Basques, now speak Basque (Bray,2013); a distinctive Basque society and economy has been created (Goikoetxea 2013); an increasing majority identify as Basque and an increasing percentage, if still a minority, want independence. ${ }^{2}$ Significantly, once violence ended, radical nationalism rebounded in popular support, winning over a quarter of the Basque

\footnotetext{
${ }^{1}$ Downing Street Declaration, 1993, para. 4. https://www.dfa.ie/media/dfa/alldfawebsitemedia/ourrolesandpolicies/northernireland/peaceprocess--joint-declaration-1993-1.pdf. Accessed 12.11.2014.

${ }^{2}$ Only 10\% feel more Spanish than Basque, Euskobarometer poll, May 2013 (http://www.ehu.es/documents/1457190/1525260/EUSBAR+MAY13.pdf, accessed 31 0ctober 2014.
} 
vote in the 2011 regional elections at the expense of the socialists, with the moderate PNV taking a similar proportion.

The end to ETA's campaign does not, therefore, mean the end of radical Basque nationalism. On the contrary, it may be strengthening at a time when the centre has been seriously damaged by the economic crisis of 2008. That crisis resurrected the perennial question of Spain's difficulty with modernisation and strengthened the Basque (and Catalan) desire for independence. The core demand now is not for independence but for the right to exercise a choice about it. This is not a right that the Spanish state is currently willing to concede. If it were granted, it would introduce a new element of uncertainty. While it is not, it represents a continuing source of grievance.

\section{Macedonia}

The Macedonian-Albanian conflict is the most recent of the three conflicts and in its present form began with the breakup of Yugoslavia and the formation of the Republic of Macedonia in 1991. In 2001, after a decade of simmering conflict, an influx of refugees and fighters from neighbouring Kosovo triggered violence that lasted 7 months and led to over 100 deaths. It alarmed the international powers in the region (EU, NATO and UN) and they quickly negotiated a peace settlement that remains in place. This may give the appearance of a conflict of minor proportions produced by short-term conjunctural processes and addressed by quick and effective external intervention. A longer-term view shows that while the conflict is recent, longer term processes exacerbated it, prevented the stabilization of settlement, and, if not addressed, could make this conflict much more serious.

\section{Multi-temporal processes and the constitution of conflict}

Today's Republic of Macedonia is based on the region of Vardar Macedonia, the north-western portion of the historic region of Macedonia. The latter was a geographical rather than cultural or political entity but it had strategic significance as the trade route from the Aegean to the Danube, and from the Black Sea to the Adriatic. It was already a complex weave of religions, languages and ethnicities before it came under 0ttoman rule in the $14^{\text {th }}$ century and the Ottomans added further to the mix (Agnew, 2007). Ottoman rule was based on religion rather than ethnicity; identities were local, ethnicity was often fluid and indeterminate and frequently followed religion rather than language; where 
ethnic conflict existed it was also, on occasion, outweighed by other cleavages (Braude, 2013; Balalovska, 2002). The decline of Ottoman power in Europe in the $19^{\text {th }}$ century created a new situation. Greater Macedonia became a zone of interlocking great power and small state rivalry, and its historically varied ethno-religious landscape was subjected to the logic of modern competitive state and nation-building.

Greece gained independence in 1830 with French and British help. Serbia achieved autonomy in 1817 largely by its own efforts, progressing to full independence with great power support. Bulgaria secured autonomy in 1878 after the Russian defeat of the Ottomans in the war of 1876-77. All three were expansionary and had designs on different parts of Greater Macedonia, basing their claims on their version of its history and ethnic composition. For the Bulgarians the peasants of Vardar Macedonian spoke a dialect of Bulgarian which made them part of the Bulgarian nation; Serbians claimed it as historically part of Serbia. Greece wanted as much of Aegean Macedonia as it could Hellenize. The three states cooperated to defeat the Ottomans in the war of 1912, after which Serbia secured most of Vardar Macedonia, Greece got a large part of Aegean Macedonia, including Thessaloniki, and Bulgaria secured Pirin Macedonia, by far the smallest portion. Bulgarian dissatisfaction led to a second Balkan War in 1913. Bulgaria attacked the combined forces of Serbia and Greece, but in doing so triggered Romanian and Ottoman invasions to recover territory they had lost to Bulgaria. The outcome confirmed the earlier division, led to a further extension of Greek territory and the emergence of Albania as a state.

As a province of Serbia, Vardar Macedonia was part of Yugoslavia after 1919, a period marked by both Macedonian and Albanian grievances against the Serbs (Balavonska, 2002). As Yugoslavia disintegrated under German invasion, Bulgaria reasserted its claims to Vardar Macedonia and occupied most of it, with some remaining with Serbia (now under German control) or going to Albania (now under Italian control). The re-establishment of Yugoslavia in 1945 saw Macedonia given national status as the Socialist Republic of Macedonia, reframing historical tensions between Slavs, Serbians and Albanians within a narrower Macedonian-Albanian compass, although also diffusing them through Albanian cultural rights and mobility within Yugoslavia.

In 1991, as Yugoslavia began to break up, the parliament of the Socialist Republic of Macedonia declared the right of its citizens to determine their future. Independence was overwhelmingly supported by referendum in September, 1991 and in November parliament approved the constitution of the new sovereign Republic of 
Macedonia. It faced external as well as internal challenges. Greece recognised its claims to statehood but objected to its name, preventing its admission to the UN under that title (Risteke and Dashkavlovki, 2011, Vancovska, 2013). By 1994 it was subjecting Macedonia to a trade blockade. Bulgaria recognised the new state, but by refusing to regard its language as separate from Bulgarian implicitly questioned whether Macedonians were a separate nation. Serbia raised similar doubts about the Macedonian claim to nationhood and delayed recognition until 1995. Albania recognised it but objected to its relegation of Albanian citizens to secondary status (Engström 2002).

The challenge from within came from the Albanian population who refused to participate in the census of 1991, contested the results and boycotted the referendum on independence in protest at the secondary status they were being accorded within the new state (Risteke and Daskalovski, 2011). That status was most evident in the preamble to the new constitution which declared the state to be the 'national state of the Macedonian people', with Albanians along with Turks, Vlachs and others given the lesser status of 'nationalities'. But it was also in provisions that declared Macedonian to be the official language and gave official status to the Macedonian orthodox church (Georgieva et al, 2011; Daskalovski 2002). In January 1992 Albanians held their own referendum (declared illegal by the government) in which a large majority voted for territorial autonomy within the Macedonian state.

In the period that followed, Macedonians made some attempt to reconcile Albanians to the new state, granting them formal political rights and seats in cabinet, and addressing their underrepresentation in state positions. This was partly in response to international pressure (Ahrens, 2007: 401- 412; Ackerman, 1999: 102-5) and partly from a desire to build a model, plural and peaceful Balkan state. The pace of reform was slow, however, and Albanian political representatives were easily outvoted (Ackerman, 1999: 88-94; Hislope, 2003:132-3). The constitution remained a serious bone of contention, for it lessened the rights Albanians had enjoyed in Yugoslavia, both formally and substantively in access to Albanian language education (Agnew, 2007, 404 ). Restrictions on language rights threatened the linguistic reproduction of the community, and - by default - made Macedonian the language of higher position in the state (Koneska, 2012, 36-40).

The Macedonian-Albanian conflict was fed by a number of streams. One was historical: the grievances carried over from the immediate and more distant pasts (Balovska, 2002). Another was social (Sofos, 2001). Albanians had a lower socio-economic 
status in a state where poverty and unemployment were high for everyone (Georgieva et al, 2011). Religious and linguistic differences made for greater social distance between the two groups than was typical of the Western Balkans (Bieber 2011). Albanians were more likely to be rural and there was a concentration of Albanians in the western and northern border areas (Neofotistos, 2004). Most of all, internal and external challenges intersected: Macedonians feared that anything less than a unitary Macedonian national state could create the conditions for its breakup (Engström 2002).

Albanian discontent in the 1990s expressed itself in low scale confrontation and occasional local violence. In 2001 more extensive and serious violence for seven months, causing on some counts close to two hundred deaths, was triggered by the influx of some 360,000 Kosovan refugees including armed rebels (Georgieva et al, 2011). This not simply put an enormous strain on local resources, it also destabilized existing inter-ethnic relations and provided unemployed Albanian youth with the resources and repertoires of violent conflict (Gleditsch, 2007). The National Liberation Army (NLA) emerged as a spinoff from the KLA, seeking equal rights for Albanians within a federated Macedonia (Vankovska, 2013; Ackerman 1999). Armed clashes in so volatile a region brought immediate international attention, offers of mediation and pressure to reach an agreed settlement: the Ohrid Framework Agreement (OFA) of 2001 remedied the immediate problems and remains in place.

\section{The significance of settlement.}

The OFA promised a substantial improvement in the position of Albanians. First and foremost, it provided for constitutional amendments that no longer privileged the nationality of Macedonians, while retaining a unitary inclusive Macedonian Republic (for detail see Georgieva et al, 2011). Albanians were no longer defined as a 'minority' or 'nationality' but as one of the constituent communities in the state. The OFA provided for increased inclusion at all political levels, with proportionality in state employment, including in the military and police. The conflict over Albanian education was addressed with new state funded Albanian language universities (for detail, see Koneska, 2012) and new language rights. A strong level of local territorial autonomy was instituted, which would permit greater Albanian local self-government in areas where they were a majority (Lyon, 2011; 2012) thus creating local areas where Albanian language and education were not only official but also predominant. 
Macedonians were also promised benefits. Macedonia would remain a unitary state and would be offered EU and NATO membership conditional on its fulfilment of the OFA obligations. This promised economic opportunities and support in a state where unemployment averaged $30 \%$ and stimulated massive out-migration (Georgieva et al, 2011) and it would give the Albanian population an economic interest in remaining in Macedonia. Just as important, it would guarantee Macedonian statehood and borders. Meanwhile, immediate and future financial and other support was made conditional on Macedonian agreement and implementation of the OFA (Koksidis, 2013 295).

Implementation has taken place, although unevenly and under pressure. Benchmarks on policing reform, and later on civil service reform, have been implemented (Vasilev, 201155, 57) However, some benchmarks are met by the dominant Macedonian and Albanian parties distributing state positions (some fictive) to party supporters, rather than by a sharing of participation and power. There has been no accession either to the EU or to NATO (blocked by Greece) and conditional promises of membership have lost credibility for many Macedonians (Ilievski and Taleski, 2009). There is also continuing Albanian demographic advance - they are now reportedly at least 700,000 out of a population that, because of economic emigration, has shrunk below 2 million.

Frustration at progress and concern at the weakening of their position has spurred Macedonian nationalist resentment, and has favoured the election of the more extreme nationalist party VMRO-DPMNE (International Crisis Group, 2011). The result has been a stronger affirmation of Macedonian nationalism at the level of the state, its symbolism, and its architecture. ${ }^{1}$ Albanians, on their side, have supported the more extreme Albanian nationalist party. Increasing tensions have led to a series of local clashes, and more generally a symbolic contest between the two dominant parties that could easily lead to more serious confrontation (Gjoni and DioGuardi, 2014).

The Macedonian case exemplifies the way that wider regional processes from the end of the nineteenth century limited the available options for Macedonians and Albanians. While historic repertoires of resentment and conflict were available to each group, the elements were forged into a conflict configuration with the formation of a Macedonian nation state in 1991. The Kosovan war triggered a period of violence: its

\footnotetext{
${ }^{1}$ Macedonian symbolism is pervasive in the capital, Skopje, with a giant statue in the main square, enormous Macedonian flags, the renovation of the fort and the building of state offices on the Albanian side of the city.
} 
importance was that it tapped into horizontal inequalities and cultural hierarchies surrounding the Macedonian-Albanian distinction and brought them sharply onto the political agenda. In so doing, it also highlighted the long-term regional dynamics that made Macedonian statehood insecure. While in principle the OFA addressed the problems, other long-term patterns have prevented its effective implementation: low state capacity, deep poverty and unevenness of economic development, a historic fluidity of state boundaries, and, in the short term, indecision by the EU and NATO.

\section{Analytic comparison}

The three cases show both differences in social, political and historical context, and similarities in the mechanisms by which political violence functions within ethnic conflicts and the paths by which it may be overcome. The geo-politics of each case are very different. Northern Ireland is a small part of the strong and (since the Scottish referendum of 2014) stable United Kingdom and financially entirely dependent on it. The Irish Republic aspires to Irish reunification in the long term, but its short to middle term concern is political stability and it engages with the British government in consensual conflict-management. The US government maintains an interest in helping resolve the conflict and both the Irish and British states have been amenable to its influence. The Basque Country AC is a small but relatively wealthy part of the fissiparous Spanish state which also faces a separatist movement in Catalonia. France has small (potentially irredentist) Basque and Catalan minorities and - like the EU - an interest in Spain surviving in its present form. Macedonia is a small and impoverished state surrounded by larger states, two of which claimed its territory in the past and, in the event of Macedonia's breakup, would reassert those claims, while both Albania and Kosovo would be open to including the Albanians of Macedonia in their state. For the moment a still fragile stability is buttressed by the presence of NATO, the UN and the EU in the region. Despite these differences, there is a notable similarity; support for the insurgents came from sympathetic co-nationals on the other side of the international border (that with the Irish Republic, France and Kosovo).

In all three cases, ethno-national relations are characterised by 'horizontal inequalities' (Stewart, 2014) but these differ markedly in extent and in type and in the capacity of the state to tackle them. Catholics and nationalists in Northern Ireland, like Albanians in Macedonia, have long experienced deep and systemic disadvantage across a wide range of political, economic and cultural fields. The British government never lacked 
the resources to address this inequality but until recently prioritised unionist concerns over nationalist ones. The economically weak Macedonian state has a limited capacity to address Albanian inequality, while also lacking the will until the crisis of 2001. The Basque Country is economically more developed and with higher levels of income than most of Spain. At least until 1979, however, it was seriously disadvantaged in cultural and national status and in political influence. The Spanish state's dilemma, in contrast to that of the British and Macedonian states, is how to secure redistribution of a portion of Basque wealth across the country while recognising Basque distinctiveness and without adding to the region's separatist tendencies.

These different political and social configurations coexist with a very similar dynamic of legitimation in each case. The political system in each case is what Jung et al (2005) have called an 'imperfect' democracy. ${ }^{1}$ For our purposes, the central feature of an imperfect democracy is that the legitimacy of the state is differentially accepted. This legitimation deficit coincides with the ethnic distinction and is often articulated by militants in terms of nationalist ideology. However it is not a function of ethnic identity or nationalist ideology alone, but rather of the structural positioning of the population. The colonial manner in which the British state established itself in Ireland in the $16^{\text {th }}$ and $17^{\text {th }}$ centuries left it with a chronic legitimation deficit for Catholics long before they became nationalist. But a state that lacks foundational legitimacy can still attain a high level of practical legitimacy by adhering to democratic norms of fairness and justice and by good governance. Northern Ireland lacked foundational legitimacy for nationalists, but it was only the breach of the latter norms, in and after the Civil Rights Movement, that completed delegitimation (see Bosi and 0 Dochartaigh, 2010). In the Macedonian case, the Macedonian parties created a new legitimation deficit by defining the state as 'their' state and by failing to do much at the practical level to ameliorate this. In the Basque Country there was an interplay between nationalist resistance to accepting the legitimacy of Spanish rule, and practical acceptance of the legitimacy of the post-78 order, not for its national but for its functional benefits and wider democratic values. The latter predominated among the Basque public after 1979, even while Basque national identification and desire for greater autonomy grew.

The imperfect democracy of each state was central to the mechanisms by which

\footnotetext{
${ }^{1}$ They see imperfect democracies as central to processes of negotiation. We see them as central to processes of conflict and the role of violence within it.
} 
violence functioned, drew support, and had effect. On the one hand, the insurgent groups emphasised and highlighted the imperfections: the 'colonial' rule of the British or the Spanish; the marginalisation of minorities by the power of majorities. Many of these imperfections were addressed in the agreed settlements - the constitutionally guaranteed autonomy accorded to the Basque Country in 1979, the consociationalism and constitutional guarantees of the GFA of 1998 and the OFA of 2001 - although for some militants, and in particular for ETA, they were radically insufficient to guarantee popular and national rights.

In each of the cases, violent insurgency was sustained by a legitimacy deficit that permitted popular understanding and tolerance of violence even among those who did not support it. ETA emerged from the long years of Francoist oppression and this assured them a significant degree of sympathy through the 1970s. In Northern Ireland the IRA emerged from the violence directed at the civil rights marchers and the wider Catholic community by the security forces, loyalists and later by the British army: while the mass Catholic public rejected IRA violence they also rejected that of the state security forces. Violence in Macedonia was initially an overspill of the Kosovan crisis; its support base, however, lay in Albanian public alienation from the procedures, policies and even the very existence of the Macedonian state.

Once violence began and became embedded, it produced a level of political polarisation that enabled it to continue. In both the Basque and Northern Irish cases, it began to take on an autonomous logic and to nurture a self-contained culture of violence - what Bar Tal (2013) calls an institutionalised 'conflict ethos' - on which it then drew. But the role of wider public tolerance remained important: where it was lacking, as for ETA increasingly in the 1990 s and 2000 s, the security options available to the state were much enhanced and the resources of insurgents reduced.

A limited amount of political violence can make a major impact in democracies, and still more in imperfect democracies. Liberal democracies have a limited range of responses they can make to political violence without incurring domestic and international costs.

They offer a range of easy targets, and are vulnerable in respect of foreign investment and international reputation. Protracted violence and emergency antiterrorist measures tend to corrupt democratic principles and practices and to damage public culture. A public legitimacy deficit makes state responses more difficult and dangerous. In each of our case studies, at different periods the central state intervened 
to repair the legitimation deficit. It did so with considerable effort and to considerable effect in the Basque Country in 1979, in Northern Ireland in the 1990s, and - with strong international help and pressure - in Macedonia in 2001.

Is anti-state violence effective in achieving its goals? States resist the claim, not least because they have a strong interest in retaining their authority, monopoly of violence, international and domestic reputation, and in deterring future insurgencies. In the cases discussed here, the insurgents did not achieve their explicit goals. Plausibly, however, violence did have an effect, if different from the intended one. In each case, it incentivised the state and the international community to act decisively to repair the wider democratic deficit. This was most evident in Macedonia, where the onset of violence focussed the attention and resources of the international community and led to the brokering of a comprehensive agreement. Here a decisive response in the early phase of crisis stopped further destabilisation and the embedding of a culture of violence. In Northern Ireland, the opportunity for such an early decisive response was not taken, the process of reform was much slower and much more indirect, with parallel security and political paths (see Todd, 2014; Ruane and Todd, 2014). In the Basque Country, the legitimation deficit was substantially addressed in the democratisation and autonomisation process and thereafter the state's responses were primarily in the realm of security.

The cases also show important features of settlement. In these cases, it was not simply, as Jung et al (2005) have argued, a matter of ensuring legitimacy for the negotiations and agreement. This also required intervention in longer term structural processes. In Macedonia, the OFA addressed two sets of historically deep problems - the role of regional instability and insecurity, and the horizontal inequality of the Albanian population. In Northern Ireland, the GFA changed the state's relation to the communities, and addressed the long-term inequality of Catholics. It did not resolve the national question, but it removed one of the reasons why Catholics became nationalist. In the Basque Country, the settlement of 1979 signalled an end to the centralising project of the Spanish state and the disvaluing of Basque culture even while it did not fully address Basque demands. 


\section{Conclusion}

The three cases discussed in this chapter are not representative of the wide diversity of ethnic conflicts, not least because each takes place within a European democracy. In each case, the conflict is fought not simply by paramilitary groups but also by political parties, supported by large sections of the populations. Each involves popular as well as elite divisions. In each case, violence has been limited, and both a political agreement and an end to violence have been secured. But these are also the reasons that the cases are significant. They show factors - the interaction of changing political strategies and change in embedded slow-moving structures - that may be missed where large powers take the opportunity to carve up territories, or where conflicting armies hold sway over them and the interest of the powerful prevails.

In these cases, violence did not follow an autonomous logic, determined by the aims of military success independent of political aims and public norms. Nor was it simply an expression of cultural divisions, myths and ideologies. Rather it was intimately if also indirectly linked to social structure and to deeply-rooted patterns of governance. For this reason, violence could be marginalised only by directly addressing these issues. This suggests the need to reconsider some of the common wisdom of peace-making and to bring in a longer temporal perspective. Our analysis suggests that the factors that are correlated with settlement stability, for example confidence building measures (Hartzell and Hoddie, 2007) and costly gestures (Glassmyer and Sambanis, 2008), succeed in building confidence because they tackle deep-set problems of legitimation and are costly because this typically involves a difficult and costly process of restructuration.

In conclusion, political violence must be placed in its temporal context if we are to understand its causes, course, and the dangers that remain when it ends. Doing so reveals causal processes that are missed in wider and flatter generalisations - the social relations and structural processes of long provenance that increase the propensity to violence and determine the success or failure of settlement initiatives. Long-term structures can be changed, and small changes in them may make a big difference in outcome. The actors most able to change them are powerful states and international actors. This is a difficult and costly task and they may be tempted to stop when political agreement is reached. We have argued that much more is needed. 


\section{References}

1. Ackerman, Alice, (1999) Making Peace Prevail: Preventing Violent Conflict in Macedonia. Syracuse: Syracuse University Press

2. Agnew, J. (2007) 'No Borders, No Nations: Making Greece in Macedonia' Annals of the Association of American Geographers, 97(2), 2007, pp. 398-422

3. Ahrens, G. H. (2007) Diplomacy on the Edge: Containment of Ethnic Conflict and the Minorities Working Group of the Conferences on Yugoslavia, Woodrow Wilson Center Press with Johns Hopkins University Press,

4. Balalovska, K. (2002) 'A Historical Background to the Macedonian-Albanian Inter-Ethnic Conflict'. New Balkan Politics, 3(4) 2002.

http://www.newbalkanpolitics.org.mk/item/A-Historical-Background-to-theMacedonian-Albanian-Inter-Ethnic-Conflict\#.VDzSXRZS6R8 accessed 16.10.2014

5. Bar-Tal, D. 2013. Intractable Conflicts: Socio-Psychological Foundations and Dynamics. Cambridge : Cambridge University Press

6. Bew, J, M. Frampton and I Gurruchaga (2009) Talking to Terrorists: Making Peace in Northern Ireland and the Basque Country, London: Hurst and Co.

7. Bieber, F. (2011) 'Introduction: Assessing the Ohrid Framework Agreement' pp 1224 in Risteska and Daskalovski (below

8. Bosi, L. And N. 0 Dochartaigh, 2010 'Territoriality and Mobilisation: the Civil Rights Campaign in Northern Ireland', Mobilization: An International Journal 15(4):405-424

9. Bosi, L. N. O Dochartaigh, and D. Pisou (2015) 'Contextualizing Political Violence', this volume.

10. Braude, B. 2013 The Success of Religion as a source for compromise in divided empires, pp 176-197 in J. McEvoy and B. O'Leary, eds, Power-sharing in deeply divided places. Philadelphia: UPenn Press

11. Bray, Zoe. (2012) 'Basque Nationalism at a Political Crossroads', in World Politics Review, Feature Report on 'People without Borders: Kurdish, Basque and Tuareg Nationalism' May 9.

12. Canny, N. (2001) Making Ireland British 1580-1650 0xford: Oxford University Press

13. Conversi, D. (1997) The Basques, the Catalans and Spain: Alternative Routes to Nationalist Mobilisation. London: Hurst and Co. 
14. Conversi, D. (2010) 'Building bridges on the road to peace. Centralism, resistance and the Basque revival', Political Geography Volume 29, Issue 8, November 2010, pp. 463-465

15. Daskalovski, Z. (2002), 'Language and Identity: The Ohrid Framework Agreement and Liberal Notions of Citizenship and Nationality in Macedonia' Journal on Ethnopolitics and Minority Issues in Europe, 1, 2-32

16. Della Porta, D. (2013). Clandestine Political Violence. Cambridge : Cambridge UP

17. Engstrom, J. (2002) 'The Power of Perception: The Impact of the Macedonian Question on Inter-ethnic Relations in the Republic of Macedonia', The Global Review of Ethnopolitics 1(3) 3-17

18. Flora, P. (ed.) (1999) State Formation Nation Building and Mass Politics in Europe: The Theory of Stein Rokkan. Oxford: Oxford University Press.

19. Georgieva, L., Memeti, A., Musliu, A. (2011) 'Patterns of Conflict Resolution in Macedonia', IBIS discussion papers, no8, www.ucd.ie/ibis/publications accessed 17 October 2014

20. Cibbons, J. (1999) Spanish Politics Today. Manchester: Manchester University Press.

21. Gjoni, R. and DioGuardi, S. C. (2014) 'Brewing Crisis in Macedonia', Open Security: Conflict and Peace Building September 23 Open Democracy, https://opendemocracy.net/opensecurity/roland-gjoni-shirley-cloyesdioguardi/crisis-brewing-in-macedonia accessed 19 0ctober 2014

22. Glassmyer, K. and Sambanis, N. (2008) 'Rebel Military Integration and Civil War Termination' Journal of Peace Research 45(3): 365-384.

23. Gleditsch, K. S. (2007) 'Transnational dimensions of civil war', Journal of Peace Research 44.3 293-309

24. Goikoetxea, J (2013) 'Nationalism and Democracy in the Basque Country (19792012)', Ethnopolitics., 12:3, 268-289

25. Grugel, J. and T. Rees (1997) Franco's Spain. London: Arnold

26. Hartzell, C. and Hoddie, M. (2007) Crafting Peace: Power-Sharing Institutions and the Negotiated Settlement of Civil Wars. University Park: The Pennsylvania State University Press.

27. Hislope, Robert (2003) "Between a Bad Peace and a Cood War: Insights and Lessons from the Almost-War in Macedonia ", Ethnic and Racial Studies 26, no. 1 129-151. 
28. Idoiaga, Gorka Espiau (2006) 'The Basque Conflict: New Ideas and Prospects for Peace' USIP Special Report, http://www.usip.org/sites/default/files/sr161.pdf Accessed 17 October 2014.

29. Ilievski, Z. and Taleski, D. (2009) 'Was the EU's role in conflict management in Macedonia a success?' Ethnopolitics 8 (5-6) 355-367

30. International Crisis Group (2011). Macedonia: Ten Years after the Conflict. Europe Report no 21211 August 2011, available at http://www.crisisgroup.org/ /media/Files/europe/balkans/macedonia/212\%20 Macedoni a\%20---\%20Ten\%20Years\%20after\%20the\%20Conflict Accessed 17 October 2014

31. Jung, C., E. Lust-Okar, E. and I. Shapiro (2005) 'Problems and Prospects for Democratic Settlements: South Africa as a Model for the Middle East and Northern Ireland?' Politics and Society, 33 (2), 277-326

32. Junto, J. A. and A. Schubert (2000) Spanish History since 1808. London: Arnold.

33. Kalyvas, S (2006), The Logic of Violence in Civil War Cambridge: Cambridge UP.

34. Katznelson, I. (2003) 'Periodization and preferences: Reflections on purposive action in comparative historical science', pp. 270 - 301 in Mahoney, J. and Rueschemeyer, D. (eds)

35. Comparative Historical Analysis in the Social Sciences. Cambridge: Cambridge University Press

36. Keating, M and Bray, Z. (2007) Renegotiating Sovereignty: Basque Nationalism and the Rise and fall of the Ibarretxe Plan, Ethnopolitics, Vol. 5, No. 4, 347-364, November 2006

37. Koksidis, P. I. (2013) 'Nipping an Insurgency in the Bud-Part II: The Success and Limits of Non-military Coercion inFYRMacedonia' Ethnopolitics 12,3 290-306,

38. Koneska, C (2012). 'Vetoes, Ethnic Bidding, Decentralisation: Post-Conflict Education in Macedonia'. Journal on Ethnopolitics and Minority Issues in Europe, $11,4.28-50$

39. Laitin, D. D. (2007) Nations, States and violence Oxford UP.

40. Linz, J. 1973 'Opposition to and under an authoritarian regime: the case of Spain' in R. Dahl ed, Regimes and Opposition New Haven: Publisher;

41. Lyon, A. (2012). 'Between the Integration and Accomodation of Ethnic Difference: Decentralization in the Republic of Macedonia'. Journal on Ethnopolitics and Minority Issues in Europe 11, 5. 80-103 
42. Lyon, A. (2011) Municipal Decentralisation: Between the Integration and Accommodation of Ethnic Difference in the Republic of Macedonia 86-105 in Risteka and Daskalovski (below)

43. McKittrick, D., S. Kelters, B. Feeney, C. Thornton and D. McVea (2004) Lost Lives: The stories of the men, women and children who died as a result of the Northern Ireland Troubles. London: Mainstream Publishing (revised edition)

44. Malesevic, S. (2013) Nation-States and Nationalisms Cambridge: Polity Press

45. Mattes, M. and Savun, B. (2010) 'Information, Agreement Design, and the Durability of Civil War Settlements' American Journal of Political Science, 54(2): 511-524.

46. Meehan, E. (2014). 'The changing British-Irish relationship: the sovereignty dimension', Irish Political Studies, 29,1., 58-75

47. Mees, L. (2003) Nationalism, Violence and Democracy: the Basque Clash of Identities. New York: Palgrave Macmillan

48. Mees, L. (2004) 'Politics, economy or culture? The rise and development of Basque nationalism in the light of social movement theory', Theory and Society 33 311-331.

49. Medrano, Juan Diez 1995. Divided Nations: Class, Politics and Nationalism in the Basque Country and Catalonia London: Cornell University Press

50. Muro, D. (2005) Nationalism and nostalgia: the case of radical Basque nationalism Nations and Nationalism 11 (4), 2005, 571-589.

51. Neofotistos, V. P. (2004) 'Beyond Stereotypes: Violence and the Porousness of Ethnic Boundaries in the Republic of Macedonia' History and Anthropology, Vol. 15, No. 1, March pp. 47-67

52. Nolan, P. (2014) Northern Ireland Peace Monitoring Report. Number Three (Belfast: Community Relations Council)

53. Pocock, J. G. A. (2005) The Discovery of Islands: Essays in British History. Cambridge: Cambridge University Press.

54. Pragnere, P (2011) "Protracted Violence in Democratic Western Europe: The Case of The Basque Country" IBIS Discussion Papers No. 12. 
55. Risteska, M. and Daskalovsk, Z (2011) One Decade after the Ohrid Framework Agreement:Lessons (to be) Learned from the Macedonian Experience Friedrich Ebert Stiftung and Center for Research and Policy Making Skopje 2011 http://www.crpm.org.mk/wp-content/uploads/AboutUS/OneDecade.pdf accessed feb 182014

56. Ruane, J. (2003) 'Theorising the transition: longue durée and current conjuncture in centre-periphery relations in Britain, France and Spain' In: Ruane, Todd, J. and Mandeville, A. (eds.) Dublin, UCD Press (eds). Old States in a New World Order. Dublin, UCD Press

57. Ruane, J. (2014) 'Conflict and reconciliation in Northern Ireland' In: Tom Inglis (ed.) Are the Irish Different? Manchester: Manchester University Press

58. Ruane, J. and Todd, J. (1996) Dynamics of Conflict in Northern Ireland: Power, Conflict and Emancipation (Cambridge: Cambridge University Press).

59. Ruane, J. and Todd, J. (2007) Path dependence in settlement processes: explaining settlement in Northern Ireland, Political Studies, 55(2), pp. 442-458.

60. Ruane, J. and J. Todd (2014) 'History structure and action in the settlement of complex conflicts: the Northern Ireland case' Irish Political Studies, 29, 1 pp. 15-34

61. Smith, C. and A. Mar-Molinero, eds. (1996) Nationalism and the Nation in the Iberian Peninsula. Oxford: Berg.

62. Sofos, S. (2001) 'Macedonia at the Crossroads' Journal of Balkan and Near Eastern Studies, 3 (2) 145-151

63. Stewart, F. (2014) 'Why horizontal inequalities are important for a shared society', Development, , 57(1), (46-54)

64. Todd, J. (2011), 'Institutional change and conflict regulation: the Anglo-Irish Agreement of 1985 and the mechanisms of change in Northern Ireland' West European Politics 34 (4) (838-858).

65. Todd, J. (2014) 'Thresholds of state change: Changing British State Institutions and Practices in Northern Ireland after Direct Rule' Political Studies 62 (3) 522-538

66. Tonge, J. et al, (2011) "So Why Did the Guns Fall Silent? How Interplay, not Stalemate, Explains the Northern Ireland Peace Process, Irish Political Studies, volume

67. Vankovska, B. (2013) Constitutional engineering and institution-building in the Republic of Macedonia 1991-2011 in S. P. Ramet, Ola Listhaug and Albert Simkus, eds, Civic and Uncivic Values in Macedonia, Macmillan 


\section{Securilatity}

68. Vasilev, George (2011) 'EU Conditionality and Ethnic Coexistence in the Balkans: Macedonia andBosnia in a Comparative Perspective' Ethnopolitics, 10(1): 51-76.

69. Wilson, A. \& Keating, M. (2009) Renegotiating the state of autonomies: statute reform and multi-level politics in Spain, West European Politics, 23(3), pp. 536-558

70. Wimmer, A. (2002) Nationalist Exclusion and Ethnic Conflict: Shadows of Modernity Cambridge, Cambridge UP

71. Wimmer, A. (2013) Waves of War: Nationalism, State Formation and Ethnic Exclusion in the Modern World. Cambridge UP 2013

72. Wright, F. (1987) Northern Ireland: A Comparative Analysis. Dublin: Gill and Macmillan

73. Zartman. I. W. (1989) Ripe for Resolution: Conflict and Intervention in Africa (2 ${ }^{\text {nd }}$ Edition). Oxford: Oxford UP. 